$\mathbb{T}$ periodica polytechnica

\author{
Transportation Engineering \\ $41 / 1(2013) 45+50$ \\ doi: 10.3311/PPtr.7096 \\ http://periodicapolytechnica.org/tr \\ Creative Commons Attribution (1) \\ RESEARCH ARTICLE
}

\section{Travel Demand Management - Possibilities of influencing travel behaviour}

\author{
Mattias Juhász
}

Received 2012-10-27

\begin{abstract}
Nowadays, one of the biggest and most challenging tasks of cities is the management of urban and suburban transport. The growth of mobility and motorization in the last centuries led into a social trap that only has recently been recognized through congestion and environmental problems. The issues mostly arise in areas where travel demand is at a high level, namely in large cities.

Handling urban and suburban transport problems could significantly influence the competitiveness of cities. In times of economic crisis and climate change it is crucial how to use scarce resources, therefore cost- and energy efficiency are becoming more and more important factors. Under these circumstances transport sector is also about to realize that new travel demand management tools can diminish the negative impacts while reasonable mobility needs can be satisfied.

In this paper the possible tools of travel demand management are categorized focusing on innovative measures. Recommendations are concluded through international best-practices in accordance with the method of Sustainable Urban Mobility Planning.
\end{abstract}

\section{Keywords}

travel demand management $\cdot$ travel behavior $\cdot$ sustainable transport systems $\cdot$ urban mobility planning

\section{Mattias Juhász}

Department of Transport Infrastructure, Széchenyi István University, Egyetem tér 1, H-9026 Győr, Hungary

e-mail:mjuhasz@sze.hu

\section{Introduction}

One of the most fashionable topics is sustainable development nowadays. Since environment-consciousness became stronger in the 70's, the analysis of the connection between economic development and environment had also got bigger attention all over the world. "The Limits to Growth", the report of the Club of Rome was published in 1972 followed by "Common Future" from UN Brundtland Commission in 1987. These reports were the first ones stressing that the pollution caused by the economic system jeopardizes the future of humankind [11]. Furthermore, Brundtland's report initiated the definition of sustainable development: "development that meets the needs of the present without compromising the ability of future generations to meet their own needs" [18]. However, sustainability has temporal and spatial dimension as well. The Brundtland definition emphasizes the temporal dimension, the so called intergeneration solidarity. In addition, the spatial dimension is about intra-generation solidarity which can be illustrated by the following definition: development that meets the needs of local people without compromising the ability of people living elsewhere to meet their own needs [4].

In Hungary - partly because of the international trends mentioned above - the first law which regulated environmental protection was issued in 1976. Transportation was identified as one of the most important cause of environmental problems in this law. Nowadays, it is still responsible for a considerable amount of airborne emissions.

The more and more serious externalities caused by the growth of motorization (including environmental pollution) appeared in the transport sector after the Second World War. It seemed that the maximum level of motorization could be at the point where nearly every household has one car ( 300-400 cars / 1000 inhabitants). Considering western European trends, now we can recognize that the saturation point is where almost everyone who is able to drive - has a car $(\sim 700-800$ cars / 1000 inhabitants) [1].

Externality is an impact in which one economic actor influences the welfare of another in a way that it is not reflected in the price. So externalities are "effects that are out of market", 
or in other words "effects that have no market" [6]. It means in practice that someone who drives a car causes a significant negative effect on the others around (e.g. pollute the air) while not compensating it, not paying for the loss, that is, the cost is shifted to the community.

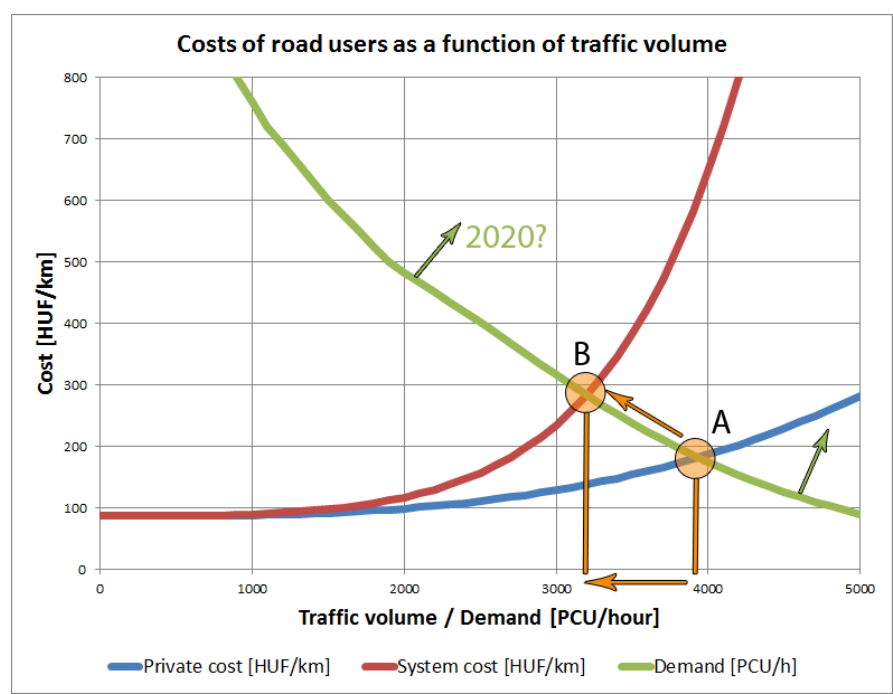

Fig. 1. An Example of congestion externality [7]

Fig. 1 shows the relation between private, social (or system) transport cost and transport demand functions which is based on a practical estimation similar to Orosz-Pásti [12] (with actualized specific costs) [7]. If road users decide on their trips based on their private costs, then the equilibrium will be at the intersection (point A) of the blue (private travel cost) and the green (travel demand) functions. It will result in $4000 \mathrm{PCU} /$ hour traffic volume on the sample road with $200 \mathrm{HUF} / \mathrm{km}$ of private cost (the cost of travel time and vehicle operation cost together) and 600 $\mathrm{HUF} / \mathrm{km}$ of system cost. If they decide on the basis of the system cost (the cost caused for other road users) the equilibrium will be at the intersection (point B) of the red (transport system cost) and the green (travel demand) functions. This case results 3200 $\mathrm{PCU} /$ hour traffic volume with $300 \mathrm{HUF} / \mathrm{km}$ of social cost. This calculation illustrates properly the recurrent congestion externality as some kind of "social trap", but it also shows a possible solution [5]. The solution in this example is the internalization of external costs, namely the inclusion of the caused social costs in road user's prices. That is the theoretical basis of urban road pricing [16].

Besides congestion, there are other external effects in transport (e.g. environmental effects, accidents etc.). The higher the traffic volume is, the more significant the external effects are, basically in cities with high population density. In these cities we usually meet more constraints simultaneously:

- available space for transport - therefore capacity - is limited,

- different protected areas (such as historical city centres),

- high volume of travel demand.
This paper focuses on the solution of urban transport problems. The topic is quite relevant because in cities - where the extent of the mentioned negative effects had grown in the last decades - there was a decrease in liveability and economic competitiveness [13]. From bigger cities residents have moved out to suburban regions where they found more liveable conditions. This so called urban sprawl effect just intensified the problems, because those who moved away still travel frequently into the city, hence they simply caused more strain to the transport system [2].

In order to diminish the negative effects and to prevent harmful processes a more sustainable organization of the transport system is needed. The main purpose is to significantly increase liveability with new innovative answers to the recent challenges.

Besides the negative effects, the economic crisis is an excellent opportunity and also a constraint to allocate the available financial resources in the most efficient way. So, we have to apply the most cost-efficient solutions to approach the optimal operation of transport systems.

\section{Possibilities to manage travel demand}

With some simplification, in certain periods of time (e.g. in peak hours) and at certain places (e.g. city centre) when transport demand is higher than the supply, traffic problems occur. From this point of view - except the "do-nothing" case - there are two types of possible solutions to manage these problems:

1 Measures increasing transport supply,

2 Measures influencing transport demand.

\section{Supply generation}

Conventionally, supply-generative measures aim to resolve the bottlenecks of transport networks. It can be resolved with an increase in capacity (e.g. widening of an existing road or creation of new parking places) or with the creation of a new link (e.g. build of a new bridge or a bypass road). These measures are effective to resolve bottlenecks or recover missing connections, but the followings have to be taken into consideration:

- As it was mentioned in the introduction, extension of a current or creation of a new network link might often be problematic in urban areas. Especially in city centres there is not enough space physically because of current structures or other restrictive factors.

- Conventional, supply-generative investments are often expensive, so funding of them is difficult in most cases. It also means that careful cost-benefit analyses (CBAs) and costefficiency analyses needed to guarantee the best value for money. It is especially important to assess the types of the expected benefits. Projects with significant environmental, accident and operating cost savings or generated revenues are mostly (economically) sustainable. However if the main benefit is travel time saving, than its reduction or disappearance 


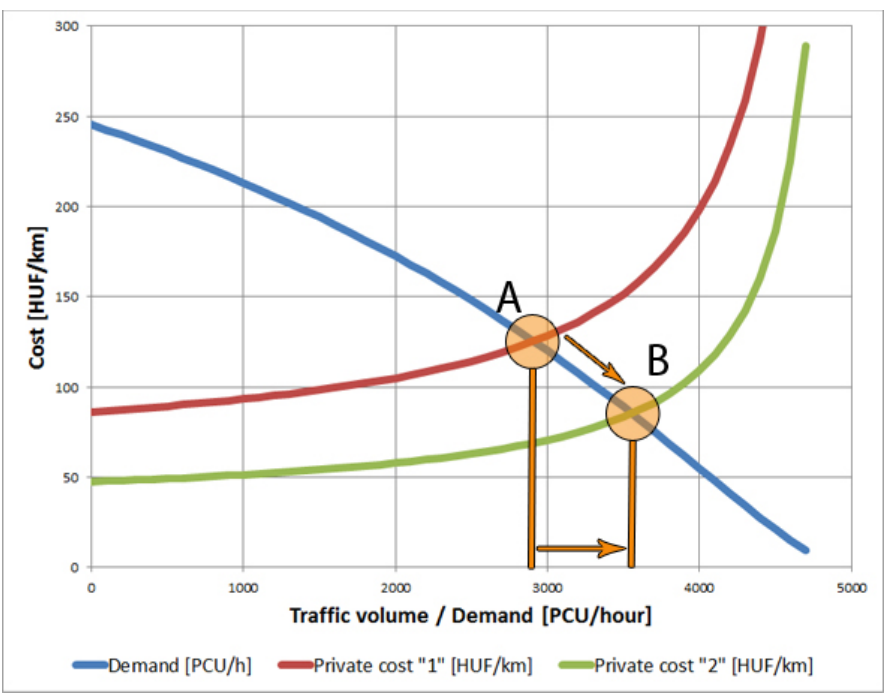

Fig. 2. An example of generated traffic [7]

can be expected within the evaluation period if we assume a constant travel time budget on a long run [14]. In addition, as CBAs lay on forecasted traffic volumes and other assumptions prudent sensitivity analyses and risk assessments needed in every case [10].

- The changes of transport supply directly influence the demand side. Up to a saturation point - which is generally not reached in urban areas - additional capacity generates additional demand (generated traffic) [9]. (see Figure 2)

- According to older studies from the UK, interventions aiming the optimization of urban road networks are not that effective. Smeed's analyses in London pointed out that drivers are not joined the traffic below a certain average speed $(9 \mathrm{mph} / \mathrm{h}=$ $15 \mathrm{~km} / \mathrm{h}$ ). But if the average speed was over that certain level due to the cancelled and modified trips or any intervention, then traffic is also started to grow up until the critical value. It means that without fiscal regulatory measures the average speed on urban roads could be around $15 \mathrm{~km} / \mathrm{h}$ on a long-term [15].

Despite the above mentioned aspects, conventional supplygenerative measures cannot be only interpreted negatively. Certain missing connection, for example bridges, extension of ring roads or interconnected trams can seriously improve the transport system of a city. At the same time there are also supplygenerative measures in the innovative sense. They could be vehicle or infrastructure improvements, which can help to make the system safer, more economic or environmentally-friendly.

\section{Influence of transport demand}

It is also possible to influence passenger transport demands. These measures can balance demand and supply and minimalize protrusive differences in order to reach the optimal usage of the transport network.

What and how can we influence? According to the subject and the method there can be two different classifications:
A. Possible fields of demand management:

A.1. Location and frequency of demand

\section{A.2. Mode choice}

\section{A.3. Route and departure time choice}

B. Possible tools of demand management:

B.1. Physical, legal and planning tools

\section{B.2. Fiscal tools}

Figs. 3, 4 and 5 show measures for influencing travel behaviour according to the previous classification.

Besides the above mentioned measures, regulation and optimization of urban freight transport and other city-management processes can also help. Innovative cities organize their logistic tasks (waste management, cleaning etc.) in accordance with their city logistic concepts. In addition, freight transport can also be regulated with low emission zones and freight charging systems or dedicated HGV lanes.

\section{Analysis of best-practices in transport demand management}

Measures for influencing travel behaviour got acclimatized in several innovative cities. There are some good solutions, which spread quickly in transport planning as a consequence of their success (e.g. bus lanes, traffic calming of city centres, reallocation of public spaces, public transport priority). There are also practices, which have been prosperously applied in certain cities, but their transferability is quite problematic (e.g. vehicle storage standards in Japan, sophisticated - time, distance and location based - public transport fares in Singapore). Other, basically auspicious but risky fiscal incentives (e.g. urban road pricing, congestion charging, HOV/HOT lanes) spread more slowly [17]. The main risks in these instruments are in connected with the social acceptance and efficiency of the controlling system.

Table 1 shows the basic assessment of several examples from each type of measures. For successful application the importance of customization to local circumstances (e.g. traditions, law-abiding behaviour, average incomes) has to be highlighted.

According to this analysis and other transport-organizing practices the following success factors can be summarized for liveable cities [8]:

- Harmonization of urban (land-use) and transport planning,

- Comprehensive regulation with efficient controlling,

- Consideration of operational aspects,

- Integration of urban and suburban transport systems,

- Enhancement of flexibility within the system,

- Intermodality and interoperability,

- Widespread application of fiscal demand management tools (user pays principle, internalization of external effects), 


\section{Location and frequency of demand}

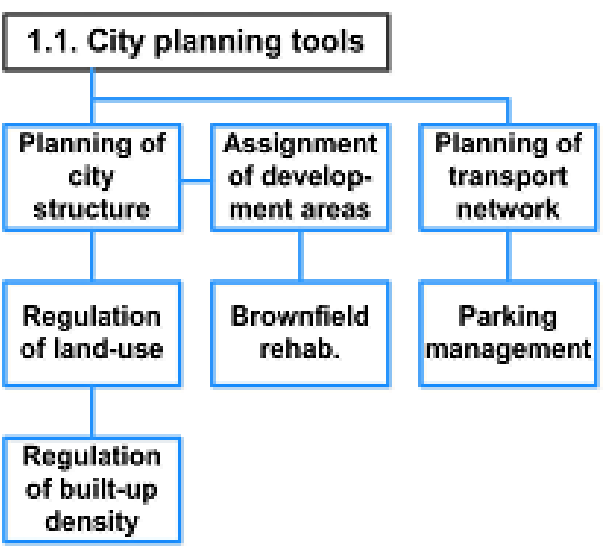

Physical, legal and planning tools

Fiscal tools

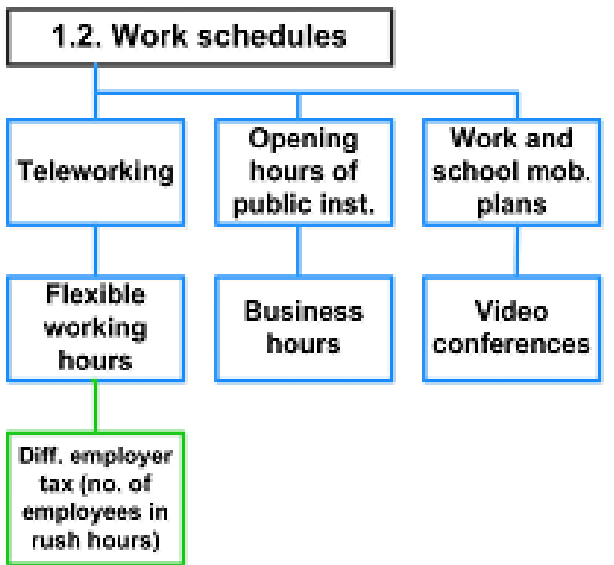

Fig. 3. Measures for influencing urban travel behavior, Part 1 [7]

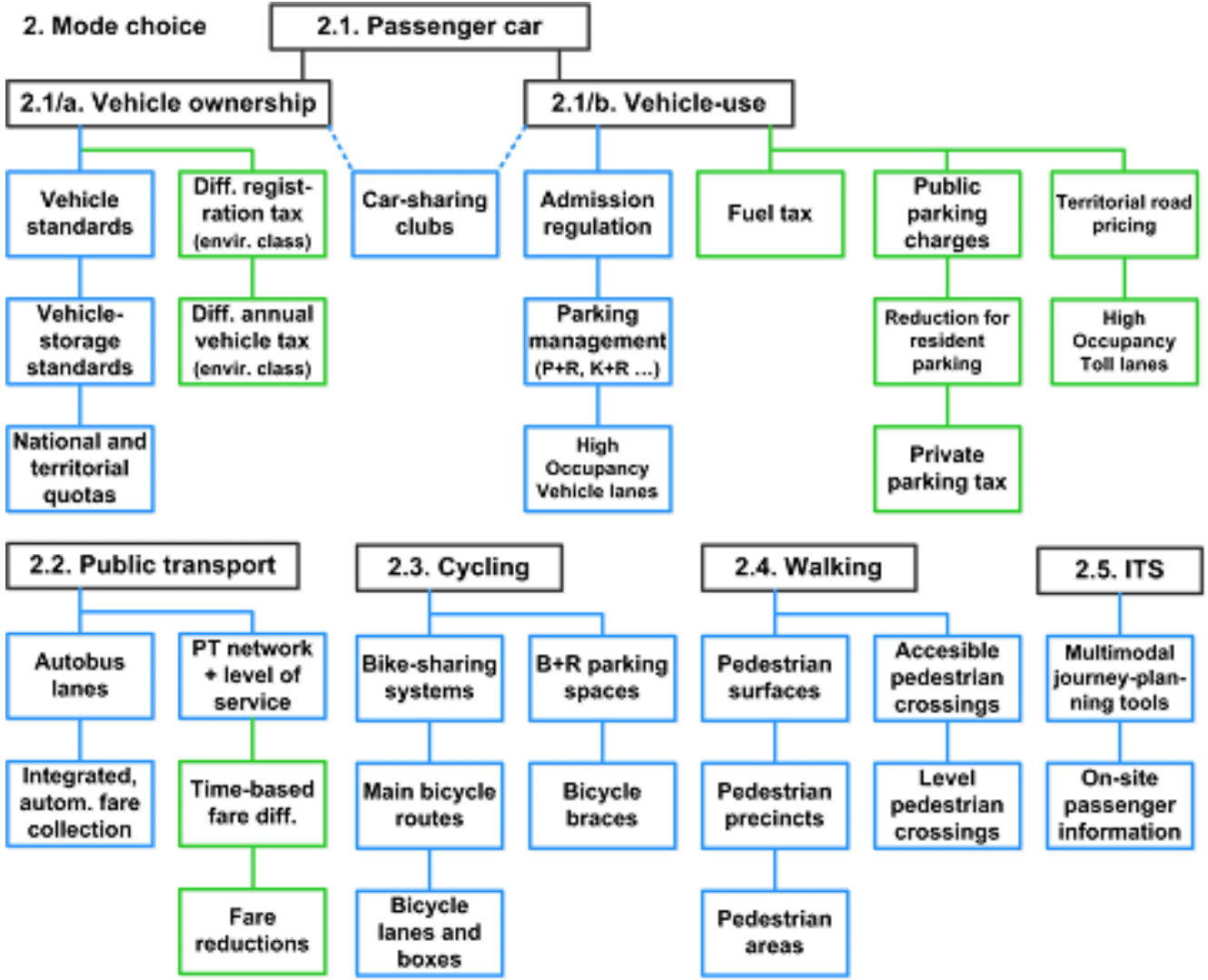

Fig. 4. Measures for influencing urban travel behavior, Part 2 [7]

- Improve the conditions of non-motorized transport modes,

- Implementation of demand-responsive services,

- Enhancement of level and reliability of service,

- Passenger orientation and user-friendliness,

- Strategic planning of energy consumption,

- Harmonization of transport demand and land-use.
Sustainable Urban Mobility Planning (SUMP) as an especially innovative approach has to be highlighted, which can foster the infiltration of the above mentioned factors. SUMP is an anthropocentric strategic planning practice, which emphasises the following aspects: quality of life, multimodality, participative planning, traffic safety, liveability, environmental pollution and cost-efficiency.

In order to promote the spread of SUMP practice, the European Union is about to ensure advantages in application for 


\section{Route and departure time choice}

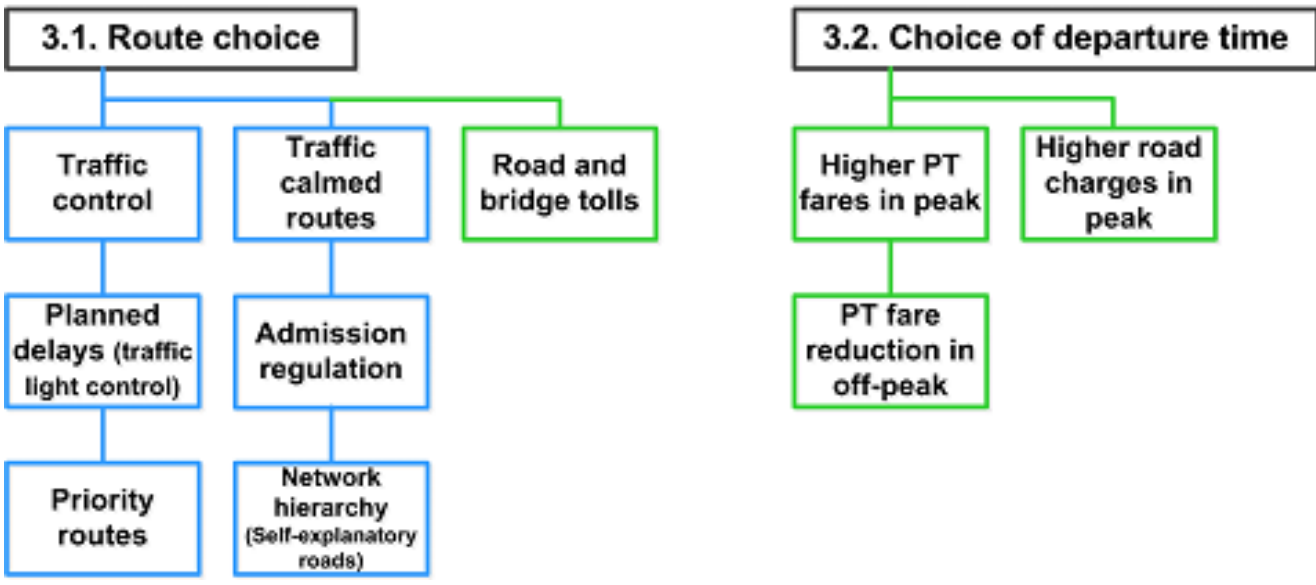

Fig. 5. Measures for influencing urban travel behavior, Part 3 [7]

Tab. 1. Practical assessment of some transport demand management tools [7]

\begin{tabular}{|c|c|c|c|c|c|c|}
\hline & \multirow{2}{*}{\begin{tabular}{|c|}
$\begin{array}{c}\text { Type of travel } \\
\text { demand } \\
\text { management tool }\end{array}$ \\
\end{tabular}} & \multirow[t]{2}{*}{ Name of tool } & \multirow[t]{2}{*}{ Internation example } & \multirow[t]{2}{*}{ Success factor(s) } & \multicolumn{2}{|c|}{$\begin{array}{c}\text { Assessment } \\
{[1-10]}\end{array}$} \\
\hline & & & & & Success & Innovation \\
\hline \multirow{3}{*}{ 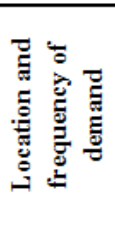 } & \multirow{2}{*}{ City planning tools } & $\begin{array}{l}\text { Regulation of built-in } \\
\text { density }\end{array}$ & $\begin{array}{c}\text { Montpellier - minimal density } \\
\text { standards }\end{array}$ & $\begin{array}{l}\text { Harmonization of city and } \\
\text { transport planning }\end{array}$ & 6 & 7 \\
\hline & & $\begin{array}{c}\text { Regulation of parking } \\
\text { places }\end{array}$ & $\begin{array}{c}\text { Vienna-Floridsdorf - } \\
\text { Carfree project }\end{array}$ & $\begin{array}{c}\text { Calm, child-friendly } \\
\text { environment }\end{array}$ & 7 & 9 \\
\hline & Work-schedules & $\begin{array}{c}\text { Work and school } \\
\text { mobility plans }\end{array}$ & $\begin{array}{c}\text { Brussels region - } \\
\text { Workplace Mob. Plan }\end{array}$ & Personalization & 4 & 3 \\
\hline \multirow{7}{*}{ 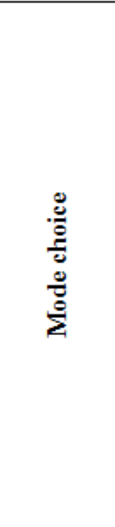 } & Vehicle ownership & $\begin{array}{c}\text { Vehicle-storage } \\
\text { standards }\end{array}$ & Japan & $\begin{array}{c}\text { Comprehensive regulation, } \\
\text { strict control }\end{array}$ & 6 & 5 \\
\hline & Vehicle use & $\begin{array}{c}\text { HOV/HOT lanes with } \\
\text { variable prices }\end{array}$ & $\begin{array}{c}\text { Maryland - } \\
\text { I-95 Express Toll Lane }\end{array}$ & $\begin{array}{c}\text { Extra service, prices } \\
\text { according to traffic volumes }\end{array}$ & 9 & 9 \\
\hline & \multirow{3}{*}{ Public transport } & Bus lanes & Nantes - Chronobus service & Speed, reliability & 8 & 5 \\
\hline & & Passenger information & $\begin{array}{l}\text { Győr - local passenger } \\
\text { information system }\end{array}$ & $\begin{array}{c}\text { Modern, user-friendly } \\
\text { devices }\end{array}$ & 9 & 2 \\
\hline & & Differenciated PT fares & Singapore - PT fare system & fairness, fiscal instruments & 6 & 7 \\
\hline & Bicycle & $\begin{array}{c}\text { Bicycle main route } \\
\text { network }\end{array}$ & \begin{tabular}{|c|} 
London - \\
Bicycle superhighway system
\end{tabular} & $\begin{array}{l}\text { Safety, speediness, optical } \\
\text { tools }\end{array}$ & 8 & 6 \\
\hline & Walking & Pedestrian areas & $\begin{array}{c}\text { Coppenhagen city centre } \\
\text { rehabilitation }\end{array}$ & $\begin{array}{c}\text { Calm environment, physical } \\
\text { restrictions }\end{array}$ & 8 & 3 \\
\hline \multirow{2}{*}{ 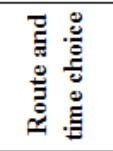 } & Route-choice & Traffic calming & $\begin{array}{c}\text { Vienna - } \\
\text { one-way street "system" }\end{array}$ & $\begin{array}{c}\text { Calm streets, priority of local } \\
\text { needs }\end{array}$ & 4 & 2 \\
\hline & $\begin{array}{c}\text { Choice of } \\
\text { departure time }\end{array}$ & Higher peak hour prices & $\begin{array}{c}\text { Stockholm - } \\
\text { congestion charging }\end{array}$ & $\begin{array}{l}\text { Well thought-out system, } \\
\text { alignment to needs }\end{array}$ & 9 & 7 \\
\hline
\end{tabular}

grants for those who use it as it is also highlighted in the White Paper [3]. Moreover, it is also possible that it can be a requirement for accessing grants in the future.

\section{Conclusions}

In this paper fundamental problems of urban transportation and the general risks of conventional supply-generative transport investments were reviewed. Possible solutions with 56 measures of travel demand management were also sketched.

Through international best-practices several success factor were determined. The importance of fiscal regulation (users pay principle), strategic transport planning and land-use planning have to be outlined among these factors.

According to this analysis the following conclusions can be drawn. In order to enhance the liveability of a large city, hard (infrastructure and vehicle), soft (traffic information, etc.) and "stick and carrot" measures have to be used in balance. Throughout their application we have to take the main and side effects into consideration. As users can naturally make mistakes (e.g. misunderstand incentives or misuse systems), it has to be taken into account in planning processes.

As a consequence of growing mobility new transport problems occurred, which need to be handled in new ways. Harmonization of urban and transport planning is needed to exploit the synergies of them. It is also important to overcome the conventional sectorial and project planning approach, and establish a multimodal, strategic planning practice in coherence with SUMP. 


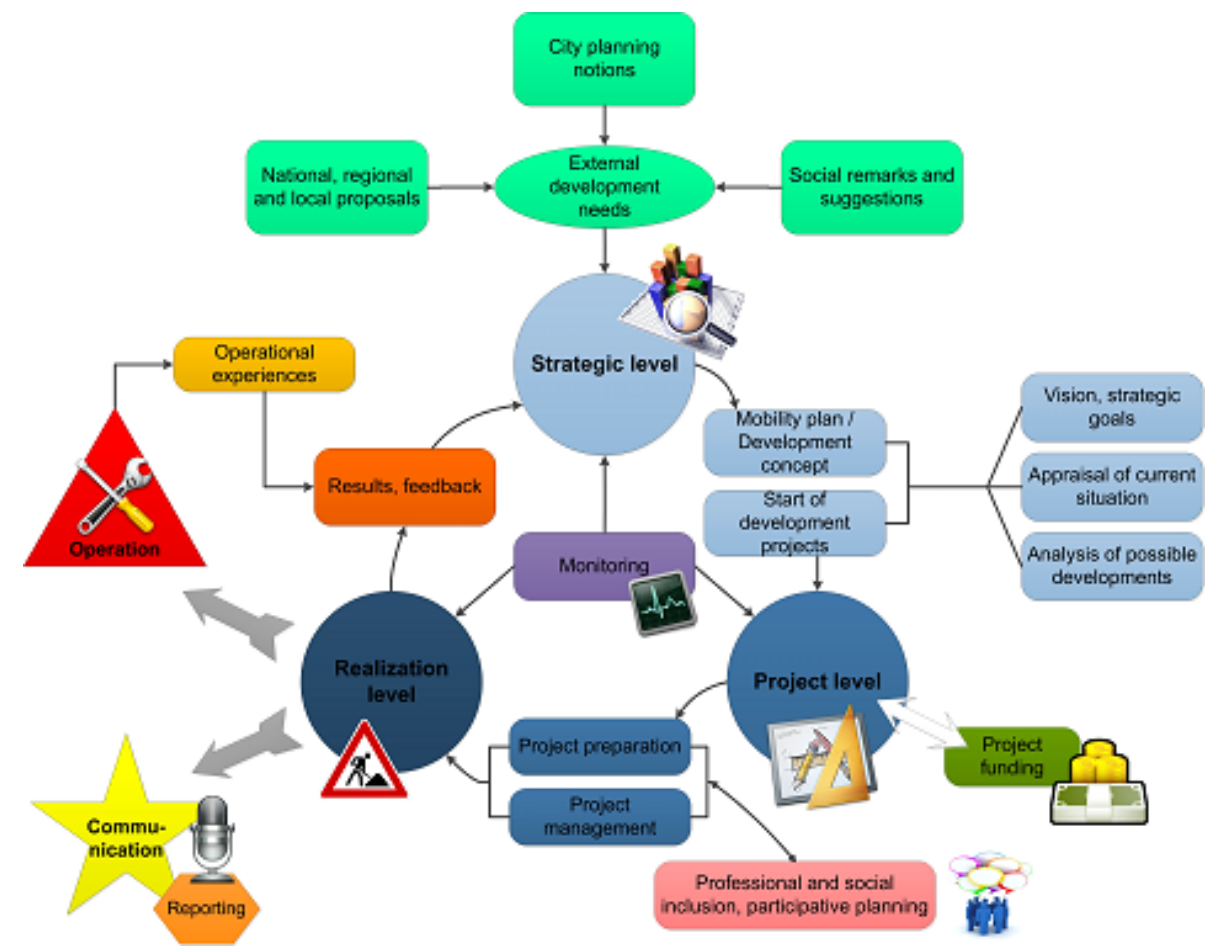

Fig. 6. A possible flowchart of transport-organization in coherence with SUMP approach [7]

To sum it up: we need to use transport-organizing measures that optimize the traffic loads on the transport network with regards to the land-use, traffic safety and environmental aspects. So we have to apply measures:

- adjusting to local needs;

- fitting to current (national, regional, local) regulations;

- in harmony with urban and transport planning;

- in coherence with stick and carrot principle;

- considering main and side effects;

- according to multimodal, regional strategic planning approach.

\section{References}

1 Borsos A, Koren C, Ivan JN, Ravishanker N, Long-Term Safety Trends as a Function of Vehicle Ownership in 26 Countries, Transportation Research Record 2280, 2012, pp. 154-161.

2 Cortright $\mathbf{J}$, Measuring urban transportation performance - A critique of mobility measures and a synthesis, Chicago: CEOs for Cities, 2010.

3 European Commission, White Paper, Roadmap to a Single European Transport Area - Towards a competitive and resource efficient transport system; Brussels, 2011. COM(2011) 144 final.

4 Fleischer T, Közlekedés és fenntarthatóság - különös tekintettel az Unió 2011-es közlekedési Fehér Könyvére, 2011.

5 Hankiss E, Társadalmi csapdák - Gyorsuló Idő, Magvető Kiadó; Budapest, 1979, pp. 55-56.

6 Juhász M, Környezeti externális költségek számszerüsítése a közúti és vasúti közlekedésben (Calculation method of the environmental external costs in road and rail traffic), BSc thesis, BME Környezetgazdaságtan Tanszék, 2010.
7 Juhász M, Budapest fóváros XI. kerület (Újbuda) városközpont közlekedésfejlesztési kérdései - A Hamzsabégi út fejlesztésének vizsgálata, (Transport development issues of the city centre of Budapest XI. District (Újbuda) - Examination of the development of Hamzsabégi Road), MSc thesis, Széchenyi István Egyetem, KTT, 2012.

8 Kerényi LS, Budapesti Rendszerterv ismertetése, presentation; Balatonföldvár, 12 May 2010. Közúti Oktatási Központ.

9 Litman T, Generated Traffic and Induced Travel; Victoria Transport Policy Institute, 2012, wWw.vtpi.org

10 Mátrai T, Cost benefit analysis and ex-post evaluation for railway upgrade projects - Ex-post economic evaluation, evaluation of traffic disturbance during construction and evaluation of travel time variability, Dissertation, Instituto Superior Téchnico, MIT Portugal Program, 2012.

11 Meadows DH et al, The Limits to Growth, Universe Books; New York, 1972.

12 Orosz C, Pásti B, Kielégíthetelen közlekedési kereslet - fejlesztési és finanszírozási lehetôségek Budapesten - útdíjakkal vagy nélkülük?, Városi közlekedés, 4, (2002).

13 Public Transport Users Association, Response to A State of Liveability A submission commenting on VCEC's draft report on liveability, 2008.

14 Schafer A, Victor D G, The future mobility of the world population, Transportation Research Part A, 34, (2000), 171-205.

15 Smeed RJ, Some statistical aspects of road safety research, Journal of the Royal Statistical Society, 112, (1949). Series A (General).

16 Smeed RJ, Road pricing: the economic and technical possibilities, HMSO, 1964.

17 Szendrő G, Congestion charging in Budapest - a comparison with existing systems, Periodica Polytechnica Transportation Engineering, 39(2), (2011), 99-103, DOI 10.3311/pp.tr.2011-2.09

18 United Nations World Commission on Environment and Development, Our Common Future, Report, Oxford University Press. Oxford, 1987. 